\title{
WYKAZ DRUKOWANYCH PRAC KS. PROF. HAB. WINCENTEGO MYSZORA*
}

\section{Druki zwarte:}

Teksty z Nag Hammadi, z języka koptyjskiego tłum. A. Dembska - W. Myszor, wstępem i komentarzem opatrzył oraz całość opracował W. Myszor, PSP 20, Warszawa 1979, ss. 232; część przedrukowana w: Apokryfy Nowego Testamentu, red. M. Starowieyski, t. 1, Lublin 1980, 121-137.

Anapausis w teologii chrześcijańskich gnostyków, SACh 5, Warszawa 1984, ss. 287. Ewangelia Tomasza. Tekst koptyjski, tłumaczenie polskie, wstęp i indeks ważniejszych pojęć (przy współpracy A. Dembskiej), Katowice 1992, ss. 67.

Podręczny słownik języka koptyjskiego, opracowanie A. Dembska - W. Myszor, Warszawa 1996, ss.182.

Ireneusz z Lyonu, Wykład nauki apostolskiej, wstęp, przekład i opracowanie W. Myszor, w: ŹMT 7, Kraków 1977, ss. 117.

Chrestomatia koptyjska. Materiały do nauki języka koptyjskiego, opracowanie A. Dembska - W. Myszor, Warszawa 1998, ss. 187.

Język koptyjski. Kurs podstawowy dialektu saidzkiego. Wydanie studyjne, Warszawa 1998, ss. 166.

Ireneusz z Lyonu, Chwała Boga żyjacy człowiek, wybór i komentarz J. Comby D. Singles, tłum. W. Myszor, Kraków 1999, ss.117.

Europa. Pierwotne chrześcijaństwo. Idee i życie społeczne chrześcijan II i III wieku, Warszawa 1999-2000, ss. 252.

Ireneusz z Lyonu, Bóg w ciele i krwi, wybór i opracowanie H.U. von Balthasar (tłumaczenie tekstu niemieckiego oraz fragmentów z pism św. Ireneusza z greki i łaciny W. Myszor), BOK 16, Kraków 2001, ss. 142.

Chrześcijanie w Cesarstwie Rzymskim II i III wieku. Wybrane zagadnienia życia społecznego, wybór tekstów źródłowych, wstęp i opracowanie W. Myszor, SACh NS 1, Katowice 2005, Księgarnia św. Jacka, ss. 288 [dodruk bez zmiany roku wydania na karcie tytułowej, 2007].

Ewangelia Judasza, wstęp, tłumaczenie z koptyjskiego i komentarz W. Myszor, SACh

NS 3, Katowice 2006, Księgarnia św. Jacka, ss. 95; [tekst, tłumaczenie i komentarz także w: Apokryfy Nowego Testamentu, t. 2: Apostołowie, red. M. Starowieyski, Kraków 2007, 895-906].

Biblioteka z Nag Hammadi. Kodeks I i II, wstęp, przekład i komentarz W. Myszor, SACh NS 7, Katowice 2008, Księgarnia św. Jacka, ss. 414.

Gnostycyzm i teologia Ireneusza z Lyonu. Zagadnienia wybrane, red. L. Lach-Bartlik, SACh NS 11, Katowice 2010, Księgarnia św. Jacka, ss. 384.

*Wykaz stosowanych skrótów zob. VoxP 25 (2005) t. 48, 437-449, lub na stronie internetowej: http://www.voxpatrum.pl/wykaz.pdf. 


\section{Artykuly:}

Tertulian, O widowiskach, tłum. W. Myszor, w: Tertulian, Wybór pism, PSP 5, Warszawa 1970, 9-113 (nadto opracowanie całości przy współpracy E. Stanuli).

Zagadnienie herezji w listach św. Cypriana, STV 9 (1971) z. 1, 147-190.

Gnostycyzm - przeglad publikacji, STV 9 (1971) z. 1, 367-424.

Apokalipsa Pawła. Wstęp, przekład z koptyjskiego, STV 10 (1972) z. 1, 163-170.

Ewangelia według Tomasza. Wstęp, przekład z koptyjskiego, przy współpracy A. Szczudłowskiej, SSHT 5 (1972) 19-42.

Wstęp, w: Hieronim, Żywoty mnichów. Dialog przeciw pelagianom, PSP 10, Warszawa 1973, 7-23.

Literatura syryjska, w: Efrem - Cyryllonas - Balaj, Wybrane pieśni i poematy syryjskie, PSP 11, Warszawa 1973, 6-26.

Nag Hammadi: teksty i ttumaczenia, STV 11 (1973) z. 1, 215-222.

Pradzieje biblijne w tekstach z Nag Hammadi, w: Warszawskie Studia Biblijne, red.

J. Frankowski - B. Widła, Warszawa 1976, 148-160 [przedruk w: Gnostycyzm i teologia Ireneusza z Lyonu..., SACh NS 11, 180-205].

Ewangelia Marii. Wstęp, przekład z koptyjskiego, STV 13 (1975) z. 2, 149-160.

Na tropach tajemnej wiedzy, „Znak” 152 (1975) 655-687 [przedruk w: G. Quispel, Gnoza, Warszawa 1988, „Znak”, 11-51; Gnostycyzm i teologia Ireneusza z Lyonu..., SACh NS 11, 15-43].

Gnostycyzm w tekstach z Nag Hammadi, SACh 1/2 (1977) 121-266.

Apokryficzny list Jakuba. Wstęp, przekład z koptyjskiego, „Znak” 275 (1977) 568-578.

Poimandres. Wstęp, przekład z greckiego, STV 15 (1977) z. 1, 205-216.

Dzieje Piotra. Wstęp, przekład z koptyjskiego, STV 15 (1977) z. 2, 169-175.

Corpus Hermeticum IV. Wstep, przekład z greckiego, STV 16,1 (1978) 184-196.

Corpus Hermeticum VI $i$ VII. Wstęp, przekład z greckiego, STV 16 (1978) z. 2, 241-247.

Idea misyjna w greckiej apologetyce II wieku, w: Materiaty Sympozjum Misjologicznego1975-1976, Zeszyty Misjologiczne ATK, t. 3, red. A. Kowalak, Warszawa 1978, 202-218.

L'état actuel des études coptologiques en Pologne, „Enchoria” 8 (1978) 25/71-28/74

(= La coptologie en Pologne, ,Le Monde Copte” 8:1979, 17-20).

Die Gnosis in den Texten von Nag Hammadi, ,Theologische Literatur Zeitschrift” 103 (1978) 236-238.

Orygenes jako systematyk, w: Orygenes, O zasadach, PSP 23, Warszawa 1979, 17-33.

Corpus Hermeticum XIII. Wstęp, przekład z greckiego, STV 17 (1979) z. 1, 245-256.

Najstarsza łacińska homilia. Wstęp, przekład z łacińskiego, STV 17 (1979) z. 2, 247-255.

Jedność i rozłam, AK 424 (1979) 252-263 [przedruk w: Gnostycyzm i teologia Ireneusza z Lyonu..., SACh NS 11, 307-316].

Wstęp i komentarz, w: Herakleon. Fragmenty, tłum. S. Kalinkowski, STV 18 (1980) z. 2, 265-298 [przedruk w: Gnostycyzm i teologia Ireneusza z Lyonu..., SACh NS $11,252-280]$.

Le paradis perdu et retrouvé dans le Tractatus tripartitus, „Folia Orientalia” 21 (1980) 149-160.

Ewangelie gnostyckie z Nag Hammadi (EvThom i fragment EvPhil), wstęp i tłumaczenie z koptyjskiego przy współpracy A. Dembskiej; część przedrukowana w: 
Apokryfy Nowego Testamentu, red. M. Starowieyski, t. 1, Lublin 1980, 121-137 [wyd. 2: 1986].

List Apostołów. Przekład z koptyjskiego, przy współpracy A. Dembskiej, w: Apokryfy Nowego Testamentu, red. M. Starowieyski, t. 1, Lublin 1980, 535-543 [wyd. 2: 1986].

Od manicheizmu do metafizyki, w: Augustyn, Pisma egzegetyczne przeciw manichejczykom, PSP 25, Warszawa 1980, 5-20.

Ewangelia Jana a niektóre teksty z Nag Hammadi, w: Orygenes, Komentarz do Ewangelii św. Jana, PSP 28, Warszawa 1981, 5-19 [przedruk w: Gnostycyzm i teologia Ireneusza z Lyonu..., SACh NS 11, 237-251].

Zagadnienie modlitwy gnostyków, TST 8 (1981) 35-44 [przedruk w: Gnostycyzm i teologia Ireneusza z Lyonu..., SACh NS 11, 155-166].

Koptyjska biblioteka z Nag Hammadi, ,Przegląd Orientalistyczny” 120 (1981) 377-385 [przedruk w: Gnostycyzm i teologia Ireneusza z Lyonu..., SACh NS 11, 78-87].

Zagadnienie pracy i zawodu w literaturze wczesnochrześcijańskiej, SSHT 15 (1982) 231-241.

Tertulian, Do Skapuli. Lekarstwo na uktucie skorpiona. Przeciw Żydom. Przeciw wszystkim herezjom (tłumaczenie z łacińskiego i komentarz), w: Tertulian, Wybór pism, II, PSP 29, Warszawa 1983, 109-146, 182-230.

Ad limina apostolorum. Podróże i pielgrzymki do Rzymu w starożytnym Kościele, SSHT 16 (1983) 87-97.

Chrześcijanie wobec świata. Problem wojny i pokoju w pierwotnym chrześcijaństwie, SSHT 16 (1983) 249-258.

Melchizedek w tekstach gnostyków, STV 22 (1984) z. 1, 203-204.

Chrześcijanie wobec świata. Zagadnienie kobiet $w$ życiu pierwotnego Kościoła, SSHT 17 (1984) 237-245.

Blisko ognia (Logion 82 Ewangelii Tomasza), w: VoxP 4,6-7 (1984) 268-271.

Oikonomia w gnostyckim Tractatus tripartitus z I kodeksu z Nag Hammadi, STV 23

(1985) z. 2, 197-215 [przedruk w: Gnostycyzm i teologia Ireneusza z Lyonu..., SACh NS 11, 120-134].

Poezja teologów [poezja syryjska], w: Muza chrześcijańska, t. 1, red. M. Starowieyski, OŻ 6, Kraków 1985, 163-172.

Das Schweigen in den gnostischen Texten, w: SACh 7 (1986) 203-221.

Oda o Norei. Wstęp, przekład z koptyjskiego, STV 24 (1986) z. 1, 197-203.

Melchizedek. Wstęp, przekład z koptyjskiego, STV 24 (1986) z. 2, 209-225.

Chrzest jako milczenie. Z gnostyckiej teologii chrztu w Tractatus tripartitus, CT 56 (1986) z. 1, 25-28 [= Die Taufe als Schweigen. Zur Theologie der Taufe im Tractatus tripartitus, CT 56 (1986) nr specjalny, 89-92].

Chrześcijanie wobec zagadnień politycznych i społecznych w III i IV wieku, „Materiały Problemowe" 18 (1986) z. 10, 104-118.

Ćwiczenia z patrologii. Wybór tekstów źródłowych, w: VoxP 6 (1986) t. 10, 79-110.

Eucharystia w ujęciu św. Ireneusza, SSHT 19-20 (1986-1987) 13-23 [przedruk w:

Gnostycyzm i teologia Ireneusza z Lyonu..., SACh NS 11, 317-328].

Eucharystia $w$ problematyce doketyzmu i gnostycyzmu, w: Pokarm nieśmiertelności, red. W. Myszor - E. Stanula, Katowice 1987, 50-56 [przedruk w: Gnostycyzm i teologia Ireneusza z Lyonu..., SACh NS 11, 218-223].

Świadectwo prawdy. Wstęp, przekład z koptyjskiego, STV 25 (1987) z. 1, 199-233. 
Sprzedawca peret $w$ „Dziejach Piotra i Dwunastu Apostołów” z VI kodeksu Nag Hammadi, w: VoxP 7 (1987) t. 12-13, 303-305.

Wprowadzenie i wybór tekstów gnostyckich w: G. Quispel, Gnoza, tłum. B. Kita, Warszawa 1988, 11-51, 155-196.

Teonasa Aleksandryjskiego list przeciw manichejczykom, Pap. Rylands 486. Wstęp i przekład, VoxP 8 (1988) t. 15, 1027-1038.

Teatr w ocenie greckich pisarzy kościelnych, w: Chrześcijanie a życie publiczne w Cesarstwie Rzymskim III i IV wieku, red. J. Śrutwa, Lublin 1988, 123-134.

Ćwiczenia z patrologii, w: VoxP 9 (1989) t. 16, 277-282.

Antonius-Briefe und Nag Hammadi-Texte, JbAC 39 (1989) 72-88 [=Listy św. Antoniego Pustelnika a niektóre teksty z Nag Hammadi, SSHT 25-26 (1992-1993) 29-44].

„Hieratike diakonia” według Klemensa Aleksandryjskiego i gnostyków, SSHT 22 (1989) 251-259.

Kierunki rozwoju chrześcijaństwa w okresie poapostolskim, w: Ojcowie Apostolscy, tłum. A. Świderkówna, PSP 45, Warszawa 1990, 5-22 [opracowanie merytoryczne całości].

Nag Hammadi: Gnosis und Mönchtum, VoxP 10 (1990) t. 19, 695-702.

Rozwój manicheizmu w Afryce Pólnocnej, w: Augustyn, Pisma antymanichejskie, tłum. J. Sulowski, PSP 54-56, Warszawa 1990-1991, 5-45 [opracowanie merytoryczne całości].

Chrześcijanie wobec świata. Praca charytatywna w pierwszych wiekach chrześcijaństwa, SSHT 23-24 (1990-1991) 193-201.

Zapisy skrybów w rękopisach z Nag Hammadi, VoxP 11-12 (1991-1992) t. 20-23, 299-303.

Symbolika perty $w$ utworach gnostyków i manichejczyków, „Rocznik Muzeum Narodowego w Warszawie" 36 (1992) 42-46 [przedruk w: Gnostycyzm i teologia Ireneusza z Lyonu..., SACh NS 11, 229-236].

Znaczenie tekstów z Nag Hammadi w badaniach pierwotnego chrześcijaństwa, „Acta Universitatis Nicolai Copernici. Nauki Humanistyczno-Społeczne. Historia” 27 (1992) 159-164 [przedruk w: Gnostycyzm i teologia Ireneusza z Lyonu..., SACh NS 11, 88-92].

Przygotowanie do kapłaństwa w IV i V wieku w Kościele Wschodnim, VoxP 13-15 (1993-1995) t. 24-29, 261-266.

Marcjon i marcjonizm, w: Tertulian, Przeciw Marcjonowi, thum. S. Ryznar, PSP 58, Warszawa 1994, 9-31 [opracowanie merytoryczne całości].

Nosiciele ducha, prekursorzy nowej ery, w: C. Vidal Manzanares, Prekursorzy nowej ery, Warszawa 1994, 7-13.

Chrześcijanie wobec świata. Małżeństwo i rozwód, SSHT 27-28 (1994-1995) 181202 [= Matzeństwo i rozwód w ocenie pisarzy chrześcijańskich w II i III wieku, w: Rodzina w społeczeństwach antycznych $i$ wczesnym chrześcijaństwie, Literatura, prawo, epigrafika, red. J. Jundziłł, Bydgoszcz 1995, 242-264].

Kształtowanie się dogmatu chrześcijańskiego, w: Nurty chrześcijaństwa, Materiały $z$ wykładów, red. M. Dobkowski - S. Kosieliński, Warszawa 1995, 17-31.

Kurt Rudolph jako badacz gnozy, w: K. Rudolph, Gnoza, Kraków 1995, 8-10 [konsultacja naukowa polskiego tłumaczenia].

Dzieje Piotra i Dwunastu Apostołów (NHC VI,1 p.1,1-12,22). Wstęp, przekład z koptyjskiego, komentarz, SSHT 29 (1996) 296-302. 
Święty Florian: legenda i kult, „Zeszyty Chorzowskie” 1 (1996) 7-9.

Orygenes $i$ gnostycy, w: Gnostycyzm antyczny $i$ współczesna neognoza, SACh 12 (1996) 22-29.

Elementy gnostyckie $w$ nowej religijności, w: Gnostycyzm antyczny $i$ współczesna neognoza, SACh 12 (1996) 70-83.

Medycyna holistyczna a neognoza, w: Gnostycyzm antyczny $i$ współczesna neognoza, SACh 12 (1996) 99-104.

Gnostycka motywacja ascezy $i$ walki ze złem, w: Drogi doskonalenia chrześcijańskiego w epoce patrystycznej. Zagadnienia wybrane, red. F. Drączkowki - J. Pałucki - M. Szram, Lublin 1997, 21-30 [przedruk w: Gnostycyzm i teologia Ireneusza z Lyonu..., SACh NS 11, 135-141].

Symbolika krzyża wedtug św. Ireneusza, SSHT 30 (1997) 97-102 [przedruk w: Gnostycyzm i teologia Ireneusza z Lyonu..., SACh NS 11, 329-334].

Ksiega Tomasza, Nag Hammadi II,7. Wstęp, przekład z koptyjskiego, komentarz, SSHT 30 (1997) 221-231.

List Piotra do Filipa (Nag Hammadi Codex VIII 2). Wstęp i przekład, w: VoxP 17 (1997) t. 32-33, 419-424.

Maryja w wypowiedziach chrześcijańskich gnostyków. Tłumaczenie i opracowanie, WST 10 (1997) 211-217.

Duch Święty w Kościele w nauczaniu Ojców Kościoła, w: Komisja Duszpasterska Episkopatu Polski, Duch Święty i jego obecność w Kościele. Program duszpasterski na rok1997/1998, Katowice 1997, 154-178.

Judeochrześcijaństwo - zagadnienie definicji i źródet, w: Judeochrześcijańskie elementy w literaturze patrystycznej, SACh 13, Warszawa 1998, 10-20.

Gnostycyzm jako faktor rozwoju teologii w II wieku, „Communio” 106 (1998) z. 4, 75-91 [przedruk w: Gnostycyzm i teologia Ireneusza z Lyonu..., SACh NS 11, 292-306].

Inskrypcja biskupa Juliusa Eugeniusa. Przyczynek do historii społecznej chrześcijaństwa na poczatku IV wieku, w: Kościót - Rodzina - Wychowanie, red. B. Olszewska, Warszawa 1998, 35-40.

Apokalipsa Piotra (Nag Hammadi Codex VII,3, p. 40,13-84,14). Wstęp przekład z koptyjskiego, komentarz, SSHT 31 (1998) 315-329.

Biblioteka z Nag Hammadi: formy literackie, VoxP 18 (1998) t. 34-35, 321-334 [przedruk w: Gnostycyzm i teologia Ireneusza z Lyonu..., SACh NS 11, 93-106].

Nauka o grzechu w przekazach gnostyckich, w: Grzech pierworodny, ŹMT 12, Kraków 1999, 9-23 [przedruk w: Gnostycyzm i teologia Ireneusza z Lyonu..., SACh NS 11, 142-154].

Kobieta w chrześcijaństwie pierwszych wieków (II i III). Partnerka, matka, opiekunka, w: Status kobiety w starożytności i średniowieczu, red. J. Jundziłł, Bydgoszcz 1999, 199-208.

Czy możliwa jest historia społeczna pierwotnego chrześcijaństwa II i III wieku?, w: Kościót -socjologia - statystyka, Księga Jubileuszowa poświęcona księdzu prof. Witoldowi Zdaniewiczowi, Warszawa 1999, 211-217.

Polskie badania nad gnostycyzmem, VoxP 19 (1999) t. 36-37, 187-192.

Ksiadz Emil Stanula (1935-1999) - w 1. rocznice śmierci, VoxP 19 (1999) t. 36-37, 725-727.

Chrześcijaństwo koptyjskie przed inwazja islamu, w: J. Drabina, Kościoły wschodnie, ZNUJ. Studia Religiologica 32, Kraków 1999, 11-32. 
Pierwsza i druga Apokalipsa Jakuba z V kodeksu z Nag Hammadi. Wstęp, przekład i komentarz, SSHT 32 (2000) 57-76.

Tysiac lat panowania Chrystusa na ziemi. Millenaryzm w ujęciu Ireneusza z Lyonu (Adversus haereses V 30, 4 - 36, 4) [przekład], SSHT 33 (2000) 5-24 [= częściowo: Millenaryzm w ujęciu Ireneusza z Lyonu, TST 19 (2000) z. 1, 27-38; przedruk w: Gnostycyzm i teologia Ireneusza z Lyonu ..., SACh NS 11, 335-357].

Stwórca świata i szatan w pismach gnostyków, w: Demonologia w nauce Ojców Kościoła, ŹMT 17, Kraków 2000, 23-38 [przedruk w: Gnostycyzm i teologia Ireneusza z Lyonu..., SACh NS 11, 167-179].

Chrystologia gnostyków. Podstawowe problemy, VoxP 20 (2000) t. 38-39, 83-92 [przedruk w: Gnostycyzm i teologia Ireneusza z Lyonu..., SACh NS 11, 106-114].

Męczennicy kościoła donatystów, VoxP 20 (2000) t. 38-39, 449-456.

Chrzest i teologia chrztu w ,Homiliach katechetycznych” Teodora z Mopsuestii, w: Chrzest na nowo odczytany, red. J. Decyk, Warszawa 2001, 11-24.

Gnostyckie apokalipsy z Nag Hammadi, w: Apokryfy Nowego Testamentu, t. 3: Apokryficzne Listy i apokalipsy chrześcijańskie, red. M. Starowieyski, Kraków 2001, 210-224.

Angelus Silesius: gnostycka czy mistyczna teologia jego pism, w: „Arkadia. Pismo Katastroficzne" 9-10 (2001) 72-85.

Wybór biskupa wświetle listów św. Cypriana, SSHT 34 (2001) 109-114.

Pax Romana i Pax Christi w wypowiedziach Euzebiusza z Cezarei, SACh 15 (2001) 191-195.

Apokryf Jana. Wstęp, ttumaczenie z koptyjskiego wersji II,2, SSHT 35 (2002) z. 1, 73-89.

Wydział Teologiczny Uniwersytetu Ślaskiego w Katowicach, w: Wyższe szkolnictwo kościelne w Polsce. Wizja Kardynała Karola Wojtyły i jej realizacja, Kraków 2002, 351-361 [nieco zmieniony tekst jako Powołanie Wydziału Teologicznego na Uniwersytecie Ślaskim w Katowicach, ,Wiadomości Archidiecezjalne” [Katowice] 70 (2002) 216-227].

Św. Efrem, przedstawiciel ,, mariologii śpiewanej”, RBL 55 (2002) 22-31.

Wydział Teologiczny - cele i obowiazki w świetle współczesnych zagrożen, w: Górny Ślask na przełomie wieków. Nadzieje i niepokoje. Świadkowie wiary, red. J. Górecki - H. Olszar, Katowice - Piekary Śląskie 2002, 11-16.

Ks. Dr Stefan Siwiec jako badacz wschodniego monastycyzmu, w: Kultura edukacyjna na Górnym Ślasku, red. A. Barciak, Katowice 2002, 296-305.

Chrześcijaństwo i nauka przed powstaniem Uniwersytetu, w: Kościół a Uniwersytet. Materiały z sympozjum (23 XI 2002), Katowice 2002, 9-13.

Dialog zbawcy. Wstęp i ttumaczenie utworu z Nag Hammadi, SSHT 36 (2003) z. 2, 490-503.

Między ortodoksja i herezja, ,Teologia Polityczna” 1 (2003/2004) 133-139.

Egzegeza o duszy. Nag Hammadi II,6. Wstęp, tłumaczenie i komentarz, SSHT 37 (2004) z. 2, 179-190.

Pierwotne chrześcijaństwo wobec pluralizmu świata antycznego, w: Kościót, świat $i$ zbawienie we wczesnym chrześcijaństwie, red. J. Naumowicz, SACh 17, Warszawa 2004, 11-18.

Grzech i pokuta w Kościele III wieku, TPatr 1 (2004) 8-18.

Wyższe Ślaskie Seminarium Duchowne i Wydziat Teologiczny Uniwersytetu Ślaskiego 
w Katowicach, w: Wyższe Ślaskie Seminarium Duchowne 1924-2004, red. J. Kupny, Katowice 2004, 79-86.

Biblioteka ks. Stanisława Makockiego, w: Monografia gminy i parafii Chetm Ślaski, praca zbiorowa pod red. J. Myszora, Chełm Sląski 2004, 385-394.

Vobis episcopus vobiscum christianus. Obraz biskupa $w$ kazaniach św. Augustyna: sermo 339 i 340A, w: Vobis episcopus vobiscum christianus. Księga Jubileuszowa dedykowana Księdzu Arcybiskupowi Damianowi Zimoniowi w dwudziestolecie postugi biskupiej w Archidiecezji Katowickiej oraz w siedemdziesiata rocznice urodzin, red. W. Myszor - A. Malina, Katowice2004, 9-22.

Chrześcijaństwo jako religia miejska w świetle pism Cypriana z Kartaginy, w: Miasto w starożytności, red. L. Mrozewicz - K. Balbuza, Poznań 2004, 487-499.

„,Ekklesia” $i$,, Kościót” w ujęciu gnostyków II i III wieku, VV 6 (2004) 185-204 [przedruk w: Gnostycyzm i teologia Ireneusza z Lyonu..., SACh NS 11, 206-217].

Der gnostische Begriff des Guten und Bösen in Plotin's Polemik mit den Gnostikern, w: Being or Good. Metamorphoses of neoplatonism, red. A. Kijewska, Lublin 2004, 127-132.

Chrześcijanie i wojna, w: Kościoły i zwiazki wyznaniowe a konflikt polsko-niemiecki na Górnym Ślasku w latach 1919-1921, red. Z. Kapała - J. Myszor, Bytom 2005, 9-22.

Origène et les gnostiques. Etat de la question, SSHT 38 (2005) nr specjalny, 48-57.

Święty Ireneusz o autorytecie Kościoła Rzymskiego, VoxP 24 (2004) t. 46-47, 87-93

[przedruk w: Gnostycyzm i teologia Ireneusza z Lyonu..., SACh NS 11, 364-370].

Ojcowie apostolscy $i$ apologeci II wieku, Literatura heterodoksyjna i św. Ireneusz z Lyonu, w: Literatura Grecji starożytnej, t. 2, Proza historyczna-krasomówstwo, filozofia i nauka, literatura chrześcijańska, red. H. Podbielski, Lublin 2005, 965-1018 [nagroda Ministra Edukacji Narodowej, zbiorowa, w 2006 r.].

Kreuz, Leib Christi und Kirche (Excerpta ex Theodoto 42 und „Die Auslegung der Erkenntnis”, NHC XI,1), w: Coptica-Gnostica-Manichaeica. Mélanges offerts à Wolf-Peter Funk, red. L. Painchaud - P.H. Poirier, Bibliothèque Copte de Nag Hammadi. Section Études 7, Québec 2006, 607-617.

Eugnostos (Nag Hammadi Codex III,3). Wstęp, tłumaczenie z koptyjskiego, SSHT 39 (2006) z. 1, 44-52.

Jezus w Ewangelii Judasza, VoxP 26 (2006) t. 49, 439-444 [przedruk w: Gnostycyzm i teologia Ireneusza z Lyonu..., SACh NS 11, 115-119].

[Żywot Andrzeja] Papirus koptyjski z Utrechtu nr 1, przekład..., w: Apokryfy Nowego Testamentu, t. 2: Apostołowie, red. M. Starowieyski, Kraków 2007, 207-210.

Koptyjskie Dzieje Piotra i dwunastu Apostołów, przekład i opracowanie..., w: Apokryfy Nowego Testamentu, t. 2: Apostołowie, red. M. Starowieyski, Kraków 2007, 569-575.

Koptyjska legenda o Szymonie i Teone, przekład i opracowanie..., w: Apokryfy Nowego Testamentu, t. 2: Apostołowie, red. M. Starowieyski, Kraków 2007, 1019-1032.

Teksty źródłowe zwiqzane z montanizmem: Ireneusza z Lyonu, Tertuliana, Pseudo-Tertuliana, Hipolita Rzymskiego, Orygenesa, Epifaniusza z Salaminy, w: Nowe proroctwo. Historia i doktryna montanizmu, red. J. Słomka, SACh NS 4, Katowice 2007, 178-179, 185-203, 207-213, 217-226, 230, 235-252.

Szenute wobec pogan i heretyków, w: Grecy i Rzymianie i ich sqsiedzi, red. K. Nawotka - M. Pawlak, „Antiquitas. Acta Universitatis Wratislaviensis” 29 (2007) 615-629. 
Enkomion of St. Pisenthios from Sheikh Abd El-Gurna. Appendix do: T. Górecki, Sheikh Abd El-Gurna (Hermitage in Tomb 1152). Preliminary Report, 2005, w: Polish Archaeology in the Mediterranean. Reports 2005, t. 17, red. M. Gawlikowski - W.A. Daszewski, Warsaw 2007, 273-274.

Walka z manicheizmem w świetle Kodeksu Justyniana, w: Byzantina Europaea. Księga Jubileuszowa ofiarowana Profesorowi Waldemarowi Ceranowi, red. M. Kokoszko - M.J. Leszka, Łódź 2007, 417-424.

Feniks $w$ gnostyckim traktacie „O poczatku świata” (NHC II,5, p.121,27-123,2), VoxP 28 (2008) t. 52/1, 677-681 [przedruk w: Gnostycyzm i teologia Ireneusza z Lyonu..., SACh NS 11, 224-228].

Gnostycyzm, manicheizm i mandaizm, w: Religie starożytnego Bliskiego Wschodu, red. K. Pilarczyk - J. Drabina, Kraków 2008, 523-563 [przedruk w: Gnostycyzm i teologia Ireneusza z Lyonu..., SACh NS 11, 44-77].

Średniowieczna religijność ludowa: dualizm $w$ świetle Interrogatio Iohannis, w: Z religijnych zagadnień średniowiecza, red. J. Drabina, ZNUJ. Studia Religiologica 41, Kraków 2008, 11-19.

A Faculty of Theology at a State University, SSHT 41 (2008) z. 2, 269-280.

„Ślaskie Studia Historyczno-Teologiczne” $w$ trudnych latach osiemdziesiatych ubiegłego stulecia, SSHT 42 (2009) z. 1, 16-21.

Kościót grzeszników i świętych. Wybrane watki z historii początków donatyzmu, SSHT 42 (2009) z. 2, 38-48.

Ireneusz z Lyonu: dzieło zbawienia i odnowy świata ( $w$ świetle komentarza do $R z$, 19-21), w: In Persona Christi. Księga na 80-lecie Księdza Profesora Czesława Bartnika, t. 1, red. K. Góźdź, Lublin 2009, 143-148 [przedruk w: Gnostycyzm i teologia Ireneusza z Lyonu..., SACh NS 11, 358-363].

Paweł Apostoł nauczycielem gnostyków?, VoxP 29 (2009) t. 53-54, 53-54 [przedruk w: Gnostycyzm i teologia Ireneusza z Lyonu..., SACh NS 11, 281-291].

Ezoteryzm gnostyków, w: Chrześcijanie w świecie późnego antyku, red. J. Naumowicz, SACh 18, Warszawa 2009, 97-106.

Teologia akademicka: jej granice i ograniczenia, SSHT 43 (2010) z. 1, 141-150.

Beatus qui erat, antequam nasceretur, VoxP 30 (2010) t. 55, 443-447.

Drabina Jakubowa jako krzyż, w: Orbis Christianus. Studia ofiarowane profesorowi Janowi Drabinie, red. E. Przybył-Sadowska - D. Szymańska-Kuta, Studia Religiologica 43, Kraków 2010, 29-33.

Z teologii wcielenia Logosu w wersji gnostyckiej, RH 58-59 (2010-2011) z. 3, 109-117.

Ewangelia prawdy (NHC I,3) - gnostycka homilia, w: Adnutiamus vobis vitam aeternam. Droga prawdy $i$ życie w przepowiadaniu homiletycznym. Księga Jubileuszowa dedykowana Księdzu Profesorowi Janowi Twardemu w 70. rocznice urodzin = „Studia Pastoralne” 7 (2011) 218-223.

Godność ludzkiego ciała w teologii Ireneusza z Lyonu, w: Fructus Spiritus est Caritas. Księga Jubileuszowa ofiarowana Księdzu Profesorowi Franciszkowi Draczkowskiemu z okazji siedemdziesiatej rocznicy urodzin, czterdziestopięciolecia święceń kapłańskich i trzydziestopięciolecia pracy naukowej, red. M. Wysocki, Lublin 2011, 287-292.

Ewangelia Marii Magdaleny. Wstęp, przekład z koptyjskiego, komentarz, SSHT 44 (2011) z. 1, 207-220. 


\section{Skrypty:}

W. Myszor - A. Szczudłowska, Chrestomatia koptyjska. Materiały do nauki języka koptyjskiego dla studentów II roku Instytutu Orientalistycznego UW, Warszawa 1974, ss. 157. Wydanie II poprawione i uzupełnione: Chrestomatia koptyjska, Materiały do nauki języka koptyjskiego, oprac. A. Dembska - W. Myszor, Warszawa 1998, ss. 187.

W. Myszor - E. Stanula, Wprowadzenie do patrologii, Kraków 1974, Wyższe Śląskie Seminarium Duchowne, ss. $220+$ ss. 149.

Patrologia. Wybór tekstów źródłowych do ćwiczeń, Katowice 1984, Wyższe Śląskie Seminarium Duchowne, ss. 399 [por. VoxP 6 (1986) t. 10, 79-110].

\section{Hasła w Encyklopediach i Słownikach:}

Słownik Polskich Teologów Katolickich, red. H.E. Wyczawski, t. 1 (A-G), Warszawa 1981: Battruszyc I., 95; Bielski Sz., s. 142-143; Bobrowski M., 172-174; Bogusławski J.K., s. 182-183; Bończyk N., s. 192-194; Borowski I., s. 201-202; Bowkiewicz J., s. 206; Chromecki T., s. 323-324; Chrościński I., s. 324-325; Ciecierski F., s. 331-332; Cytrynowski J., s. 346-347; Dębiński I., s. 391-392; Golański F.N., s. 542-545.

Słownik Pisarzy Antycznych, red. A. Świderkówna, Warszawa 1982 (wznowienia): Apokaliptyczna literatura, s. 71; Apologeci chrześcijańscy, Apophtegmata Patrum, Apostolscy Ojcowie, s. 77; Eirenaios, s. 173n; Gnostycy, s. 212n; Hagiografowie, s. 219n; Ignatios, s. 252n; Kyrillos Al., s. 280; Kyrillos Hier., s. 281; Paulus Ap., s. 348n.; Proklos, s. 390; Sokrates Schol., s. 425n; Theodoretos, s. 451n.; Theodoros Mops., s. 453.

Herezje, w: Katolicyzm A-Z, red. Z. Pawlak, Poznań 1983, 131-134 (wznowienia).

Encyklopedia Katolicka, Lublin: Cecylian, t. 2 (1979), k. 655-656; Cyprian z Kartaginy, t. 3 (1979), k. 690-693; Gnostycyzm w ocenie Ojców Kościoła, t. 5 (1989), k. 1205-1208; Gnoza w teologii patrystycznej, t. 5 (1989), k. 1210-1212; Hegemonius, t. 6 (1993), k. 622; Hermes Trismegistos, t. 6 (1993), k. 785; Hermetyczne pisma, t. 6 (1993), k. 785-786; Herezje, ocena, t. 6 (1993), k. 753-754; Iszobucht, Ishobokht, t. 7 (1997), k. 542; Izaak z Amidy, t. 7 (1997), k. 584; Izaak z Antiochii, t. 7 (1997), k. 584; Jan Malalas, t. 7 (1997), k. 920-921; Jan z Paralos, t. 7 (1997), k. 927; Kainici, t. 8 (2000), k. 329; Karpokrates, t. 8 (2000), k. 893; Koptyjska literatura, t. 9 (2002), k. 808-813; Koptyjski Kościół, t. 9 (2002), k. 815-824; Koptyjski ryt, t. 9 (2002), k. 824; Koriun, t. 9 (2002), k. 853-854; Kurisumala, t. 10 (2004), k. 254; Makary, Makarios, t. 11 (2006), k. 868; Marek Gnostyk, t. 11 (2006), k. 1278; Maruta z Maiferkat, t. 11 (2006), k. 1481-1482; Maruta z Tagrytu, t. 11 (2006), k. 1482; Massona z Meridy, t. 12 (2008), k. 161; Menas, t. 12 (2008), k. 525; Michat z Nisibis, t. 12 (2008), k. 833-834.

Słownik wczesnochrześcijańskiego piśmiennictwa Wschodu, red. M. Starowieyski, Warszawa 1999: Archelites, k. 23; Gnostyckie pisma w BG, k. 76; Hermetyczna literatura, k. 89-90; Jeu księgi, k. 125-126; Koptyjska literatura, k. 131-135; Manichejskie pisma, k. 146-149; Nag Hammadi, k. 159-172; Pistis Sophia, k. 187-188.

Lexikon für Theologie und Kirche: Ptolemaios, Gnostiker, t. 8 (1998), k. 735-736; Seleukianer, t. 9 (2000), k. 435; II. Apokryphe Schriften, Paraphrase des Sem, Traktat des Shem, t. 9 (2000), k. 446; Theodotos Gnostiker, t. 9 (2000), k. 1425-1426. Religia. Encyklopedia PWN, Warszawa, t. 1 (2001): Anastazy Synajski 212; Andrzej 
z Krety 219; Arianizm 327; Ariusz 329; Bardezanes 484; Bazylides 507/508; Gnostycyzm, t. 4 (2002) 200-201; Patrologia, t. 8 (2003) 29-32; Patrystyka, 32-34.

Słownik wczesnochrześcijańskich pisarzy I-VII, C. Vidal Manzares, wyd. 2, Warszawa 2001 [nowe opracowanie prawie 100 haseł, bibliografia, ss. 239 wobec ss. 145 wyd. 1. z 1996].

Powszechna encyklopedia filozofii, Lublin: Corpus Hermeticum, t. 2 (2001), s. 292294; Gnostycyzm, t. 3 (2002), s. 805-808; Gnoza, t. 3 (2002), s. 808-813; Herakleon, t. 4 (2003), s. 353-354; Hermes Trismegistos, t. 4 (2003), s. 394-395; Hermetyzm, t. 4 (2003), s. 395-399; H. Jonas, t. 5 (2004), s. 379-380; Karpokracjanie, t. 5 (2004), s. 509-510; Karpokrates, t. 5 (2004), s. 510-511; Leisegang Hans, t. 6 (2005) s. 300-301; Nag Hammadi, t. 7 (2006), s. 475-476, Pleroma, t. 8 (2007), s. 284-285; Barbelognostycy, t. 10 (Suplement 2009), s. 48-51; Setianie, t. 10 (Suplement 2009), s. 396-398.

Encyklopedia kultury bizantyńskiej, red. O. Jurewicz, Warszawa 2002: Gnostycy, s. 187; Herakleon, s. 203; Herezje, s. 204-205; Hezychazm, s. 206; Homousios, s. 212; Jakobici, s. 226; Magia, s. 319; Manicheizm, s. 325; Monofizytyzm, s. 356; Paulicjanie, s. 398; Teopaschici, s. 469; Trishagion, s. 480; Tryteizm, s. 482; Tymoteusz II Ailuros, s. 485; Tymoteusz III, s. 485.

\section{Recenzje:}

Früchristliche Reden zur Osternzeit, Düsseldorf 1967 - RBL 22 (1969) 45.

J. Jungmann, Liturgie der christlichen Frühzeit, Freiburg 1966 - RBL 22 (1969) 44-47.

W. Dziewulski, Zwycięstwo chrześcijaństwa w świecie starożytnym, Wrocław 1961 SSHT 4 (1972) 355-358.

M.D. Scholer, Nag Hammadi Bibliography 1948-1969, Leiden 1971 - CT 43 (1973) z. 3, 225-227.

K. Prümm, Gnosis an der Wurzel des Christentums?, Salzburg 1971 - CT 43 (1973) z. 4, 183-185.

H. Quecke, Das Markusevangelium saidisch, Barcelona 1972 - STV 13 (1975) z. 2, 225-226.

W. Kosack, Lehrbuch des Koptischen, Graz 1974 - STV 14 (1976) z. 1, 273-277 [= w języku francuskim: „Folia Orientalia“ 18 (1977) 292-295].

M. Starowieyski, Ojcowie Żywi, Kraków 1978-1980 - SSHT 14 (1981) 363-366.

F. Szulc, Struktura teologii judeochrześcijańskiej w świetle badań Jeana Daniélou, Lublin 1982 - SSHT 15 (1982) 291-292.

F. Drączkowski, Kościót-Agape wedtug Klemensa Aleksandryjskiego, Lublin 1983 SSHT 16 (1983) 268-269.

E. Pagels, The Gnostic Gospels, Versuchung durch Erkenntnis, Die gnostischen Evangelien, Frankfurt 1981 - SSHT 16 (1983) 270-271.

H.J. Seeliger, Kirchengeschichte-Geschichtstheologie, Düsseldorf 1981 - CT 54 (1984) z. 2, 185-187.

E. Sauser, So nahe steht uns die Ostkirche, Frankfurt 1980 - SSHT 17 (1984) 265-266.

S.K.J. Wiśniewska, Teologia Angelusa Silesiusa, Warszawa 1984 - SSHT 17 (1984) 266-268.

P. Jay, L'Exégese de saint Jerome d'après son „C Commentaire sur Isaie”, Paris 1985 - CT 56 (1986) z. 3, 194-196. 
C. Scholten, Martyrium und Sophiamythos im Gnostizismus nach den Texten von Nag Hammadi, Münster 1987 - SSHT 21 (1988) 282-286.

W. Godlewski, Le monastère de St. Phoibammon, Warszawa 1986 - SSHT 21 (1988) 286-289.

Po co nam Ojcowie Kościoła? rec. książki: J. Kelly, Poczatki doktryny chrześcijańskiej, Warszawa 1988 - „Więź” 34 (1991), nr 11-12, 253-258.

H. Pietras, Jedność Boga, Kraków 1990 - VoxP 10 (1990) t. 18, 357-361.

New Testament and Gnosis. Essays in honour of R.M. Wilson, Edinburg 1983 - VoxP 10 (1990) t. 18, 365-367.

Ch.M. Tuckett, Nag Hammadi and the Gospel Tradition, Edinburgh 1986 - VoxP 10 (1990) t. 18, 367-368.

J.M. Robinson, Nag Hammadi Library in English, Leiden 1988 - „Bibliotheca Orientalis" 48 (1991) 550-551 [po polsku: VoxP 10 (1990) t. 18, 362-365].

Le Traité Tripartite, par E. Thomassen - L. Painchaud, Québec 1989 - „Chronique d'Egypte" 68 (1993) 347-350 [po polsku: VoxP 10 (1990) t. 19, 922-926].

Ambrosius Mediolanensis, De sacramentis, Fontes Christiani 3, Freiburg 1990 - CT 61 (1991) z. 4, 205-208.

F. Drączkowski, Miłość synteza chrześcijaństwa, Lublin 1990 - SSHT 23-24 (19901991) 330-331.

B. Altaner - A. Stuiber, Patrologia, Warszawa 1990 - „Więź” 34 (1991) t. 11-12, 253-258.

Fontes Christiani-CT 63 (1993) z. 1, 111-113; CT 64 (1994) z. 1, 87-93.

Y. Torisu, Gott und Welt. Eine Untersuchung zur Gotteslehre des Irenäus von Lyon, Nettetal 1991 - CT 63 (1993) z. 1, 187-188.

J. Zandee, The Teaching of Sylvanus, Leiden 1991, „Chronique d'Egypte” 15 (1995) 422-426 [wersja polska: VoxP 11-12 (1991-1992) t. 20-23, 489-493; SSHT 25-26 (1992-1993) 403-405].

H. Jonas, Religia gnozy, Kraków 1994 - „Znak” 484 (1995) 193-197.

B.A. Pearson, Gnosticism, Judaism and Egyptian Christianity, Minneapolis 1990 SSHT 30 (1997) 361-363.

A. Khosroyev, Die Bibliothek von Nag Hammadi, Einige Probleme des Christentums in Ägypten während der ersten Jahrhunderte, Altenberge 1995 - „Orientalia” 65 (1996) z. 3, 370-374 [wersja polska: SSHT 30 (1997) 363-366].

B. Częsz, Zwiqzek Ducha Św. z Kościołem w ujęciu św. Ireneusza $i$ w interpretacji montanistycznej, Poznań 1991 - SSHT 30 (1997) 367-368.

W.G. Röhl, Die Rezeption des Johannesevangelium in christlich-gnostischen Schriften von Nag Hammadi, Frankfurt 1991 - SSHT 30 (1997) 369-370.

M. Franzmann, Jesus in the Nag Hammadi Writings, Edinburgh 1996 - VoxP 16 (1996) t. 30-31, 488-491 [wersja niemiecka: „Bibliotheca Orientalis” 55 (1998) 249-251].

S. Bralewski, Imperatorzy późnego cesarstwa rzymskiego wobec zgromadzeń biskupów, Byzantina Lodziensia I, Łódź 1997 - SSHT 31 (1998) 441-443.

A. Nocoń, Ioannis Cassiani doctrina de amicitia iuxta coll XVI: Fontes classici et patristici verae amicitiae partes constitutivae, Romae 1996 - SSHT 33 (2000) 398-399.

R. Murawski, Wczesnochrześcijańska katecheza, Płock 1999 - SSHT 33 (2000) $399-401$. 
A. Mazewski, Minucii opus ut „protrepticum” ad veritatem inquirendam, Romae 1999 - SSHT 33 (2000) 401-402.

F. Drączkowski, Patrologia, Pelplin - Lublin 1998 - SSHT 33 (2000) 403-405.

T. Kołosowski, Od wolności wyboru wyznania do przymusu religijnego. Ewolucja pogladów biskupa Augustyna z Hippony podczas schizmy donatystycznej w Afryce Pótnocnej, Piła 2000 - SSHT 35 (2002) z. 1, 164-166.

J. Naumowicz, Geneza chrześcijańskiej rachuby lat. Historyczno-teologiczne podstawy systemu Dionizego Mniejszego, Kraków - Tyniec 2000 - SSHT 35 (2002) z. 1, 167-169.

J. Słomka, Pokarm i ofiara. Refleksja eucharystyczna wczesnych Ojców Greckich, Łódź 2000, SSHT 35 (2002) z. 1, 169-172.

L. Mateja, Oblicza miłosierdzia. Historyczne uwarunkowania kształtowania doktryny o miłosierdziu. Studium dziet Tertuliana i świętego Cypriana, Kraków 2003 SSHT 36 (2003) z. 1, 270-273.

N. Widok, Physis w pismach Grzegorza z Nazjanzu. Studium z teologii patrystycznej, Opole 2001 - SSHT 36 (2003) z. 1, 273-276.

A. Brent, The imperial cult and the development of Church order. Concepts and images of authority in paganism and early Christianity before the age of Cyprian, Leiden 1999 - SSHT 37 (2004) z. 2, 291-292.

Ch. Gieschen, Angelomorphic Christology. Antecedents and early evidence, Leiden 1998 - SSHT 37 (2004) t. 2, 292-293.

J. Skoczyński, Neognoza polska, Kraków 2004 - SSHT 38 (2005) z. 2, 487-489.

K. Schatz, Prymat papieski od poczatków do współczesności, Kraków 2004 - SSHT 38 (2005) z. 2, 489-493.

F. Szulc, Syn Boży w „Pasterzu” Hermasa. Świadectwo chrystologii judeochrześcijańskiej, SACh NS 2, Katowice 2006 - SSHT 40 (2007) z. 2, 472-473.

D. Zagórski, Model doskonalenia chrześcijańskiego w świetle eksportacji pastoralnych Grzegorza z Nazjanzu, Toruń 2007 - SSHT 42 (2009) z. 1, 240-244.

S. Strękowski, Sofiologia św. Grzegorza z Nyssy. Elementy teologii trynitarnej $i$ antropologii w Homiliach do Pieśni nad Pieśniami, Kraków 2006 - SSHT 42 (2009) z. 1, 244-248.

Metafizyka i teologia. Debata u podstaw, red. R.J. woźniak, Kraków 2008 - SSHT 42 (2009) z. 1, 248-254.

D. Kasprzak, Duszpasterze V wieku. Studium porównawcze myśli pasterskiej św. Piotra Chryzologa i Salwiana z Marsylii, Kraków 2008 - SSHT 42 (2009) z. 2, 211-215.

H.E. Mayer, Historia wypraw krzyżowych, Kraków 2008 - SSHT 42 (2009) z. 2, 215-218.

A.A. Napiórkowski, Jezus Chrystus objawiony i objawiajacy. Chrystologia fundamentalna, Kraków 2008 - SSHT 42 (2009) z. 2, 219-220.

K. Modras, Omelia copta attribuita a Demetrio di Antiochia, Sul Natale e Maria Vergine, Roma 1995 - SSHT 43 (2010) z. 1, 168-170.

G. Jaśkiewicz, Doketyzm jako wyraz relatywizmu w teologii, Ząbki 2009 - SSHT 43 (2010) z. 1, 171-174.

J. Grzeszczak, Pomiędzy utopiq i eschatologiczna nadzieja. Idea papieża anielskiego $w$ średniowiecznym i renesansowym profetyzmie, Poznań 2008 - SSHT 43 (2010) z. 1, 181-186. 
A. Posacki, Ezoteryzm i okultyzm - formy dawne i nowe. Aspekty filozoficzno-teologiczne i praktyczno-duszpasterskie, Radom 2009 - SSHT 43 (2010) z. 1, 206-210.

Źródta Myśli Teologicznej, t. 45-51, WAM, Kraków 2008-2009 - SSHT 43 (2010) z. 2, 446-453.

M. Szram, Ciało zmartwychwstałe w myśli patrystycznej przełomu II i III wieku, Lublin 2010 - SSHT 44 (2011) z. 1, 298-301.

„Vox Patrum” - od r. 1998-2012 (t. 32-57): stały recenzent.

\section{Prace redakcyjne:}

Ambroży, Hexameron, tłum. W. Szołdrski, wstęp A. Bogucki, opracowanie merytoryczne i indeksy W. Myszor, PSP 4, Warszawa 1969.

Tertulian, Wybór pism. Do męczenników, Preskrypcja przeciw heretykom, O widowiskach, O modlitwie, O chrzcie, O cierpliwości, O pokucie, tłum. E. Stanula - W. Kania - W. Myszor, wstęp E. Stanula, opracowanie merytoryczne i indeksy W. Myszor - E. Stanula, PSP 5, Warszawa 1970.

Hieronim, Żywoty mnichów, Dialog przeciw pelagianom, tłum. W. Szołdrski, wstęp, opracowanie merytoryczne i indeksy W. Myszor, PSP 10, Warszawa 1973.

Efrem - Cyryllonas - Balaj, Wybrane pieśni i poematy syryjskie, z syryjskiego tłum. W. Kania, wstęp, opracowanie całości i indeksy W. Myszor, PSP 11, Warszawa 1973.

Orygenes, Przeciw Celsusowi, tłum. S. Kalinkowski, wstęp S. Kalinkowski - E. Stanula, opracowanie merytoryczne S. Kalinkowski - W. Myszor - E. Stanula, PSP 17, Warszawa 1977.

Teksty z Nag Hammadi (Apokryficzny List Jakuba, Ewangelia prawdy, Wypowiedź o zmartwychwstaniu, Ewangelia Tomasza, Ewangelia Filipa), z koptyjskiego tłum. A. Dembska - W. Myszor, wstęp, komentarz i opracowanie całości W. Myszor, PSP 20, Warszawa 1979.

Orygenes, $O$ zasadach, tłum. S. Kalinkowski, wstęp i opracowanie merytoryczne S. Kalinkowski - W. Myszor - E. Stanula, PSP 23, Warszawa 1979.

Augustyn, Pisma egzegetyczne przeciw manichejczykom, tłum. J. Sulowski, wstęp, opracowanie merytoryczne i indeksy W. Myszor, PSP 25, Warszawa 1980.

Orygenes, Komentarz do Ewangelii św. Jana, cz. 1-2, tłum. S. Kalinkowski, wstęp i opracowanie merytoryczne W. Myszor - E. Stanula, PSP 28, Warszawa 1981.

Tertulian, Wybór pism, II: Do pogan, Świadectwo duszy, Do Skapuli, Lekarstwo na uktucie skorpiona, Do żony, Zachęta do czystości, Przeciw Żydom, Przeciw wszystkim herezjom, tłum. zbioru i wstęp Cz. Mazur - K. Obrycki, opracowanie całości W. Myszor - K. Obrycki - E. Stanula, PSP 29, Warszawa 1983.

Opuscula. Studia Antiquitatis Christianae, t. 7, red. W. Myszor - E. Stanula, Warszawa 1986, ss. 310.

Pokarm nieśmiertelności, red. W. Myszor - E. Stanula, Katowice 1987, ss. 271.

Ojcowie Apostolscy (Klemens Rzymski, Ignacy Antiocheński, Polikarp, Męczeństwo św. Polikarpa, List Barnaby, Hermas, Homilia z II wieku (II List Klemensa), Meliton z Sardes), tłum. A. Świderkówna, wstęp i opracowanie merytoryczne całości W. Myszor, PSP 45, Warszawa 1990.

Augustyn, Pisma przeciw Manichejczykom (O pożytku wiary, O dwóch duszach, Sprawozdanie z dyskusji z Fortunatem, List Podstawowy, Przeciw Adimantowi. Przeciw Feliksowi), tłum. J. Sulowski, wstęp i opracowanie merytoryczne całości W. Myszor, PSP 54, Warszawa 1990. 
Augustyn, Przeciw Faustusowi, księgi I-XXI, tłum. J. Sulowski, wstęp i opracowanie merytoryczne całości W. Myszor, PSP 55, Warszawa 1991.

Augustyn, Przeciw Faustusowi, księgi XXII-XXXIII, Przeciw Sekundynowi, thum. J. Sulowski, wstęp i opracowanie merytoryczne całości W. Myszor, PSP 56, Warszawa 1991.

Tertulian, Przeciw Marcjonowi, tłum. zbioru S. Kalinkowski - W. Myszor - K. Obrycki - S. Ryznar - E. Stanula, wstęp i opracowanie W. Myszor, PSP 59, Warszawa 1993.

zebrała Ludmiła Lach-Bartlik 